Biografistyka Pedagogiczna

Rok 6 (2021) nr 1

ISSN 2543-6112; e-ISSN 2543-7399

DOI: $10.36578 /$ BP.2O21.06.16

\title{
Marek Budajczak*
}

\section{Education in Cybernetic Illumination by Marian Mazur Edukacja w cybernetycznej iluminacji Mariana Mazura}

Abstract: The article presents the cybernetic approach and justifications of the same kind for highlighting flaws in the functioning of today's, still unchanged, mass school, proffered by Marian Mazur, the founder of the Polish school of cybernetics. This author analyses all the important dimensions of school functioning - from the content, through methodology to its organisation - pointing to the rationality of an optimising cybernetic approach to education, which is perfectly consistent with the common sense feeling about the weakness of schools. Although Mazur's analyses date back to the 1960s, they seem to be applicable today not only to our country, but also to the entire world.

Keywords: Marian Mazur, cybernetics, education, school, navigating

* Marek Budajczak (ORCID: 0ooo-0oo1-9126-6207) - dr hab., Professor of Adam Mickiewicz University in Poznań (AMU); head of the Alternative Education Laboratory at the Faculty of Educational Studies, AMU; Email: putaiszy@amu.edu.pl. 
Navigare necesse est

\section{Introduction}

T is possible to get the impression that, apart from the terms from its Lextremes, in the middle part of the title of this proposal - if it is not only an awkward linguistic formula - lies an almost oxymoronic clash of interrelated terms: cybernetics and illumination.

The former is supposed to describe a phenomenon from the lowlands of the 'sub-empirean world', while the latter seems to be rooted in the 'highest heavens'. As for their orientation, one could say that the first one manifests a human hubris, heading through the moral shortcuts towards the world of full control over the bodies and mental life of untermenschen, while the second shows humility concerning the specificity of the creative spirit that does not submit to external commands or training.

However, if theological metaphors and normatively marked characterological terms were to be abandoned in order to limit the analysis only to the empirical social and individual world of people, cybernetics would describe a transdisciplinary theoretical and technical complex oriented at the 'controlling' (i.e., navigating) of purposive systems - artificial and natural ones - and therefore to control them; illumination, on the other hand, would be an 'uncontrollable' variant of human intellectual experiences, in which the Whole Truth is experienced without the mediation of reasoning, by means of a sudden 'discovery'.

In order to develop and justify the enigmatic concept of 'illumination' used here, it is necessary to indicate that it carries at least two meanings: the more common, exoteric - shedding a specific type (here: 'cybernetic') of light on a given object (here: on education), next to the already mentioned esoteric sense: spiritual enlightenment, insight into the essence of education itself, using cybernetic, so to speak, 'meditation'.

Cybernetics, on the other hand, although distanced today by computer science and neuroscience, still inspires multidisciplinary research at the interface between technology and anthropology.

An almost forgotten figure in this context is the founder of the Polish school of cybernetics - specifically in areas like psychocybernetics and sociocybernetics - Marian Mazur (1909-1983), who applied his cybernetic insights and diagnoses to numerous fields of anthropology as a science of humanity. As 
its important dimension is also pedagogical and educational reflection and the implementation of the latter, it is obvious that the author had to make himself at home in this field as well.

Regardless of the specifically Polish and historical (the communist period of Poland) context of Mazur's educational remarks, they seem to be possible to be generalised both spatially and temporally, as mass school in today's globalised world has relatively the same characteristics, essentially remaining unchanged in its shape for two centuries, because it was only that long ago (and because the trauma of war was its only motivation) that it was born in the totalitarian state of royal Prussia.

\section{Marian Mazur - a biographical sketch}

Marian Mazur is the thinker whose educational views we will be examining here. In the science chest of drawers, he was assigned to cybernetics as the field of technical engineering, the big sister of the present computer science. His version of cybernetics, pioneered in our country, focused on the social and psychological applications of cybernetics. The Polish school of cybernetics was oriented towards sociocybernetics (with its orientation towards social control) and psychocybernetics (with regard to the optimal state of self-control). In both of these understandings, we deal with the contexts of pedagogy for there is no pedagogy as a theory of broadly understood education, without taking into account the social and psychological conditions for effective navigation by teachers and society in general in the worlds of their pupils and students, as well as for educational self-navigation carried out by the latter themselves. The term steering - cybernetic in its origin - can therefore be considered one of the key categories of pedagogical thinking. Mazur's analyses of education in this sense, apart from his academic, popularising (also educational) and social activity for teachers, constitute a sufficient basis for recognising him as an original pedagogical thinker and a reliable social practitioner of education. ${ }^{2}$

1 Different to Maxwell Maltz's or Mark Falstein and Bobbe Sommer's versions of psychocybernetics.

2 Some pedagogical contexts are also to be found in works by Jolanta Wilsz, e.g., J. Wilsz, Poglądy profesora Mariana Mazura na temat edukacji w kontekście teorii systemów autonomicznych, „Kształcenie Zawodowe: Pedagogika i Psychologia”, 15 (2013) pp. 125-149. 
It will be worthwhile, however, taking a short look at Marian Mazur's biography. ${ }^{3}$ He lived in the years 1909-1983. Although he was born with talents in science and technology, his mother also instilled in him a passion for music, poetry and the visual arts. He completed his polytechnic studies as an electrical engineer at the age of 25, gaining such recognition in this field that - after one year of military service - he was appointed head of the electrical measurement laboratory (which he had to build from scratch) at the State Telecommunications Institute. Two years later, he created an innovative, on a global scale, theory and laboratory model of an automatic telephone connection system, whose pilot implementation was interrupted by the outbreak of World War II. The foundations of his cybernetics were created during the tragic period of the German occupation (his mother died in the Auschwitz concentration camp), but unfortunately the first extensive volume devoted to this concept was destroyed during the Warsaw Uprising, in which Mazur took an active part. During the first years after the war, on behalf of the Ministry of Industry and Trade, he assisted in the development of the newly acquired Polish 'Western Lands'. During these years he could not work on his version of cybernetics, because the communist authorities considered it to be a bourgeois pseudoscience. So, he took up electrothermy, being successful in this field (he was elected chairman of its research committee by the International Electrothermal Organization), and he also lectured at the Warsaw University of Technology. He dealt with technical terminology, and in 1966 he published the groundbreaking Cybernetic Theory of Autonomous Systems, to be later chiselled and developed in other well-known publications, including Qualitative Information Theory (1970) and the best known: Cybernetics and Character (1976). He lectured on his theory at the Sorbonne and Rice University (concurrently working in the USA on the artificial intelligence programme for NASA), and presented at numerous national and international conferences. The bibliography of his works consists of about 200 items. He died of pneumonia, or rather of a failure of the state health system, in 1983. He was never honoured with the national title of full professor.

3 Biographical data acquired from: M. H. Górny, Naukowcy wyklęci. Część I - Ojciec polskiej cybernetyki, „Pro Fide Rege et Lege”, 79 (2018) pp. 62-91; J. Lechowski, Życiorys naukowy profesora Mariana Mazura (1909-1983), „Postępy Cybernetyki”, 10 (1987) z. 2 , pp. $7-20$. 
Symptomatic of cybernetically interpreted educational references is the series of publications entitled $O$ szkole cybernetycznie (Cybernetically about School), published by Marian Mazur in the years 1965-67 in Argumenty, a socio-cultural weekly. It is this series that will be the subject of our reflection here, along with the text entitled Jaka szkoła? (What school?), included in the weekly Przegląd Tygodniowy in 1984, with the conscious omission of other, certainly no less important, educational-related texts by this creator of Polish cybernetics. ${ }^{4}$

\section{Mazur's general statements on education}

In his general commentary on the condition of mass school and calling it a fossilised creature', Mazur states that the benefits of cybernetics for education can be located on three levels or in as many dimensions:

- cybernetic metadidactics (in assessing the rationality of school teaching in general),

- cybernetic education methodology, and

- cybernetic educational content as a distinct learning subject.

He further presents his cybernetic, systemic and 'steering' concept of feedback between the environment and the 'organs' of the human organism (as well as between themselves), which are, according to the original cybernetic terminology adopted by him, as follows:

- correlator (the individual information organ - the nervous system with its centre in the form of the brain);

- homeostat (a set of mechanisms regulating the functioning of the body by maintaining a dynamic internal balance);

- accumulator (a set of organs within the human body specialised in energy conservation for various types of physiological functioning and autonomous operations).

4 Here one could count such texts like: Cybernetyka i charakter, Warszawa 1976; Homeostaza społeczna, in: Procesy samoregulacji w oświacie. Problemy homeostazy społecznej, eds. M. Pęcherski, J. Tudrej, Warszawa 1983, pp. 107-115; Cybernetyka, in: Szkoła a postęp techniczny, ed. T. Nowacki, Warszawa 1962, pp. 185-230; Tajemnice charakteru czyli poznaj samego siebie, Warszawa 1999. 
It is worth adding that this steering activity is controllable, which in turn creates a fundamental possibility for the emancipation of the subject of activity (including, of course, the student as the subject of learning). Unfortunately, the feedback loops favouring a student's emancipation are 'almost inexistent' at school, as Mazur believes.

An important part of his conception is also the normative, but justifiable, differentiation of information groups into:

- useful information - useful for school students when they reach adulthood, useful in terms of the processes of self-control in the environment;

- lengthy information (today we would say redundant), repeating the former useful information;

- ('sterile') information noise, that disturbs the reception of what is really useful.

Mazur derives from this division a number of consequences, including that the task of the school is to provide students with the most necessary (this is an intriguing accent, indicating a possible hierarchy of importance in this regard) useful information, while respecting the didactic need to repeat the information (and thus increase its lengthiness), in order to establish it properly in a student's memory resources.

Let us add immediately that Mazur's estimates that at school we are basically dealing with the transmission of information noise (it would be - according to his calculations $-80 \%$ of the lesson time), to the detriment of useful information (honoured only by $5 \%$ of the lesson time), were empirically supported by the results of the regular and large socio-educational research by Zbigniew Kwieciński. ${ }^{5}$

Mazur makes one more dichotomous distinction, important for his perception of the school, in terms of useful information. These are firstly factual knowledge - the most accurate answers to given questions, and then views inaccurate information on a subjective basis.

Contrary to appearances, it is in this respect that he believes that education does not mean having numerous, detailed information at one's disposal (remembering facts), but the inherent ability to create views and discuss them with other people.

5 Z. Kwieciński, Socjopatologia edukacji, Olecko 1995. 
Only the messages that are needed frequently and immediately are important. The others can be found in the sources (today by just clicking on them), and Mazur himself considered independent, conscious and systematic searching through these to be favourable in the process of a person's enculturation. He also considered the ability to distinguish useful information from information noise as equally important.

As a consequence, Mazur challenges - while doing so in a rational manner, and therefore with appropriate justifications - the traditional school division into lessons, classes, subjects, as well as the teaching methods used in school and the dominant concept of selecting the content of education, criticising especially the constant elbowing of the school curricula with consecutive subject content. $^{6}$

Mazur himself, however, but only to facilitate the readers' reception of his argumentation, adopts the order of analyses of what school is, according to the said 'school subjects', starting the title of each of his analytical pieces with the phrase: 'Wrong with...'

Opinions on school teaching of Polish language and literature

First: „Źle z polskiego” (Bad grade for Polish and literature).

Although in the field of language education it is important for Mazur to know the formal rules of the spelling and grammar of our national language, he nevertheless calls for their simplification (with much tolerance for the mistakes made by students - only the adepts of culture). ${ }^{7}$ And we, in this regard, would also appeal for their internal coherence.

The fact that the referenced author seems to be right here is justified by the fact that Polish teachers (along with scholars) still use an archaic set of grammar terms dating back to the end of the 18 th century (sic!). ${ }^{8}$

6 M. Mazur, Twór skostniaty, „Argumenty”, 27 (1965) pp. 1, 6; M. Mazur, Źle z języków obcych, „Argumenty”, 40 (1965) pp. 2-3.

7 M. Mazur, Źle z polskiego, „Argumenty”, 35 (1965) pp. 5, 8.

8 The Polish grammar terminology was first proposed by Onufry Kopczynski in 1788 in his "Grammatyka dla szkół narodowych na klassę I" (Grammar for Grade I of National Schools). 
Let us mention here the casus of imiestów (participle). It is, as the Wikipedia definition says, ${ }^{9}$ an impersonal form of a verb, but it is not known how it differs from other impersonal verbal forms. The newfangled Polish division into adjectival and adverbial participles, in turn, seems to contradict the logic of the original idea in the Polish language.

In old Polish, the calques of Latin words (after all, Latin was the school language for centuries): nomen - 'name' and verbum - 'word', were the names of grammatical categories meaning respectively: noun (or - which is questionable - adjective) and verb. So, 'imiesłów' is a kind of 'noun-verb' (nominal-verbal word), a word that displays at the same time, though from different perspectives, the features of both of these grammatical categories. Unfortunately, only adjectival participles have this quality, while adverbial participles are purely verbal. As an example, let's take the participles formed from a Polish verbal root: kup- (the morpheme: buy).

And so, the active adjectival participle kupujacy (the buying one) is a term for 'a man who buys something now or ever' (and therefore with an emphasis on the name of an object - here, a human being), and at the same time it is a term for 'a man who performs a specific activity' (and so with an emphasis on the act of buying).

The passive adjectival participle in its following two varieties of the perfect one: kupiony (a bought one) and the imperfect: kupowany (being bought) is, respectively, 'the object that was or will be the subject of a specific and finished action' or 'something that the specific action is/was/will be aimed at'. Contrary to adjectival participles, a 'simultaneous' adverbial participle indicates an activity performed during the occurrence or duration of another activity, and therefore it is completely 'verbal' (not nominal), as is the 'anterior' adverbial participle, indicating an activity that precedes another and posterior activity. Contrary to adverbial participles, the so-called gerund or deverbal noun: kupowanie (buying) is precisely an imiestów (nominal-verbal word).

The case discussed above, regardless of the disputes about it among scientists, can be generalised to the poor condition of scholastic grammar as such. These inconsistencies, as well as the direct or indirect reduction of grammar terminol-

9 Imiesłów, Wikipedia, https://pl.wikipedia.org/wiki/Imies $\% \mathrm{C}_{5} \% 82 \% \mathrm{C}_{3} \% \mathrm{~B} 3 \mathrm{w}$, Retrieved: 11.03.2021. 
ogy to Latin, only cause confusion in students, becoming, for those who want to learn about their human world and function effectively in it, useless.

In addition, if - regardless of the structural differences between languages - a universal grammatical terminology, made simpler for educational reasons, was adopted in the international community, and some achievements in this area already exist, then learning foreign languages would also turn out to be easier.

As for language education through literature, according to Mazur, getting to know the history of one's own ethnic language through the canonical texts of national literature is really valuable, especially for the etymological understanding of today's vocabulary, although it (as for the set of obligatory school reading) should be radically truncated to those texts he called 'vital' in order to give students the opportunity to familiarise themselves with the canon of world literature.

This familiarisation with the reading, if the basic data (author's bio, form and content) concerning these texts is omitted, should be an exchange of students' views on them, and not of mastering the 'knowledge' about them, because there are no 'sacred' interpretations of subsequent school texts. The texts themselves should be proposed to students in samples for their approval, but never imposed on them, because otherwise they may have an aversion to literature once and for all.

Mazur also believes that the literary words should be enriched with their artistic and musical correlates (direct connections and creative references), even by adding a separate teaching subject devoted to 'culture in general' to the school curriculum. The postulate still remains unfulfilled.

As part of Polish language and literature lessons, says Mazur, students should be helped, among other competences, in acquiring the skills of manual writing and that of using a 'typewriter' (today we would say: with the use of a computer text editor), and in the second case of so-called touch typing, as well as the ability to substantively prepare oneself to create (also in the sense of compliant editing) adequately structured and not verbose utility texts (and not useless essays with futile analyses of Bolesław Prus's Lalka novel The Doll - or Ignacy Krasicki's fables), texts that are useful in various social contexts: papers, speeches, discussion replicas, conference moderations, protocols, applications, conclusions, complaints, etc. It is also necessary for the purposes 
of writing for students to master the skills of using library resources (and now also internet resources).

Rhetorical skills - in giving thematic speeches - are also important, in his opinion. In this respect, Mazur also states the following: 'Most of the lecturers, political activists, etc. monotonously read the previously prepared texts, or hang around and stutter, trying to improvise. ${ }^{10}$ If such quantifications and qualifications are generally exaggerated, then unfortunately they are locally accurate.

And to sum up Mazur's proposals in relation to Polish language and literature lessons or, more broadly, ethnic language lessons, one should say: Not much to add, not much to subtract!

Opinions on school teaching of foreign languages

Second: „Źle z języków obcych” (Bad grade for foreign languages).

When it comes to teaching foreign languages, it may be questioned whether Mazur's claim that each student has to master four foreign languages is, nomen omen, useful. ${ }^{11}$ With the dominance of the English language nowadays, German seems to be of use to cultural historians, French to philosophers, and Russian to almost no one. In this regard, obviously, we ignore the business usefulness of other world languages.

As for the methodology of language education itself, Mazur is right: Ministry experts and publishers of school materials need to generate lists of words, phrases and sentences for compulsory mastering by students (although the frequency method suggested by the author is not necessarily the most useful one). In addition to vocabulary, as in the case of the proper national language, it is also necessary to master the basics of the grammar of a foreign language. In both of these ranges, repetition is essential for effective memorisation. Students also need to speak a foreign language and translate texts into it as faithfully as possible from living Polish (or any proper one), without being limited to 'simple blocky' sentences like: 'In the picture I can see ....'

10 M. Mazur, Źle z polskiego.

11 M. Mazur, Źle z języków obcych.

12 This is a characteristic phrase repeated by Polish high school graduates during English exams. 
Mazur's remark on the usefulness of knowing Latin (and, let us add, ancient Greek) morphemes and whole words, which are the basis for scientific and technical terminology, is also correct, but without forcing students to master the grammars of both of these dead languages. Elegant Latin maxims are only useful to those few students who aspire to the world of a sophisticated humanistic culture.

Opinions on school teaching of history, geography and science

Third: „Źle z historii” (Bad grade for history).

History, according to Mazur, has no value in itself, and is useful only in 'searching for generalisations, detecting mechanisms of typical historical events',13 for understanding the present and predicting the future based on them - and thus for controlling oneself in social relations. It is not only about political relations, but also about economic and cultural ones, either neglected or simulated by the school. History, therefore, should be the history of civilisation and, we would add, the universal civilisation, and not only the Western one.

In terms of size, history should be reduced to a reasonable minimum, and presented in a 'synthetic' form, from general to specific issues, using tabular synoptics for at the same time when Leonardo da Vinci created his masterpieces, in Poland and other countries, also something important happened, and not rarely in connection with those events on the Italian ground.

The narrative (also fictional and, more broadly, artistic), even very detailed, would be useful in highlighting a given historical mechanism, as, for example, in various special issues of the Battle of Grunwald.

Knowledge of items of information from history should concern answers to the questions: who played an important role in the biggest events, what happened, where it was and, of course, when it happened - and here, clearly defined requirements are necessary at school, especially for the point on which Mazur places a strong emphasis, that is, in the context of examinations, and also in relation to other school subjects.

It is essential to give students the opportunity to express their views on this matter. Answers to the question: 'why?' are the domain of views. One should

13 M. Mazur, Źle z historii, „Argumenty”, 11 (1966) pp. 4, 6. 
also not avoid a thorough criticism of historical events. At this point, the author commented on and proposed an interesting 'cybernetic, optimising analysis of the legendary history of Philippides' - a messenger from Marathon. Mazur transforms the positive opinions of the runner's sacrifice into critical remarks: Why was it necessary to hurry with the information about the victory, since there was no threat to Athens and no need to prepare for the defence of the city? Wasn't sending one courier instead of using a relay of envoys a manifestation of the organisational indolence of the Greek command?

For an objective presentation of historical events, without 'instilling illusions' about them, ${ }^{14}$ it would also be important to confront the Polish approach to Polish history with the approaches in those of other nations.

Finally, Mazur forbids education from trivialising history by presenting it in a prepared version 'for children', without some 'adult' inadequacies.

His only brief hint is that geography should be treated in the same spirit: syntheticity. What is the sense for a child to remember the names of all the capitals of African countries (names otherwise prone to change, and also on other continents) or all about the minerals found in the $\mathrm{X}$ valley, when geographical atlases arranged according to various criteria are available? It does not mean, however, that fundamental orientation as to the main parts of the world, as well as identifying countries' names, along with their relative location, would be optional for an average educated person. Again, these areas of knowledge should be clearly defined for the requirements of tests and examinations.

Although Mazur does not say anything about them, it is obvious that, mutatis mutandis, the same approach should also apply to those school subjects covered by the English word science, that is, biology, physics and chemistry. Today they seem to be extended far too much if usefulness is concerned (with special cases of: 'the structure of Paramecium caudatum', 'kinetic-molecular theory of an ideal gas' or 'van der Waal's intermolecular force').

Opinions on school teaching of mathematics

Fourth: „Źle z matematyki” (Bad grade for maths).

14 Ibid. 
In this article, Mazur demands a reduction in the quantitative and qualitative content range of mathematics education at school. ${ }^{15}$ Even if mathematics were to teach methods of reasoning, in his opinion this dimension is missing in school. There is, however, 'art for the sake of art' - a vague riddle that, for good time management, it would be better for the student to engage in solving rebuses, playing chess or bridge.

There are only a handful of students (no more than 10\% in an average class) who are passionate about and capable of mathematics, and only those who will study the secondary school mathematics curriculum (he himself mentions its last three years) within an introductory year (it would be enough time to do it) at mathematical, physical, and engineering (let's also add business) colleges. The social benefit of such a solution would be significant, not only for individuals but also for the national economy.

Information noise should be eliminated from mathematics lessons, in favour of enriching them with information useful for all. For example, according to Mazur, the tedious calculation of logarithms is worthless, because even engineers use logarithmic slide rules when needed.

And he is not a supporter of poor content and the low level of students' advancement at all, because he believes that it would be worthwhile and useful to explain differential and integral calculus.

In his opinion, the teaching of mathematics should be based on deduction - from general to particular, not the other way around - on induction (with the 'grinding' of dozens of fictitious tasks), and as far as means are concerned, the issues should be implemented with the extensive use of graphs and diagrams.

There is no value in describing circles on a trapezoid, while programming skills are lacking, in a broader sense than the current computer programming at schools, that is, implementing the art of creating schedules, algorithms, graphs (much easier to do in computer science classes today). Due to its practical value, statistics should also be included in the school mathematical curriculum.

Mazur's general remark in this reference was as follows: 'The school should [...] teach not only mathematical operations, but also criticism of data and

15 M. Mazur, Źle z matematyki, „Argumenty”, 27 (1966) pp. 1, 6. 
their interpretation ${ }^{16}$, which would certainly also be useful in the methodology of empirical research teaching, and also as part of pedagogical studies. All this was suggested in order to optimise our individual and social functioning.

\section{Comments on educational methodology}

The metadidactic remarks scattered in the previous articles are presented by Mazur in the articles: School without Fear, Teaching Integration and What School?.17

He considers the school to be a parody of the judiciary (and more broadly the postulate of 'social justice'): Firstly, one day, the teacher assumes the role of an advocate helping his student-client (and simultaneously all the students in the class, always treating them separately) to understand a certain issue, supporting them in dealing with difficulties with that issue. The next day the teacher turns into a prosecutor, who wants to prove the ignorance of this student by taking them out for evaluation or organising a test, and finally, the teacher becomes a judge, who assesses the state of the student's knowledge. From the student's position as a constant suspect, a situational guilty man emerges, whose total sentence (we are prolonging this metaphor here) is included on the early or final certificate. Tension and anxiety are constant and indelible from school. Isn't that cruelty? Mazur asks. ${ }^{18}$

The final exam (also all other forms of checking knowledge) is a war from which you return with or on the shield. Yet the rationality and mission of the school is to 'teach what is useful' and nothing else. And this is connected, as noted earlier, with the function of gradual practicing for proficiency within a certain range and repeating and replaying necessary messages to oneself. After all, social practice knows multiple exams, such as when obtaining a driving licence. Why cannot these forms of examination also be considered rational at school? For Mazur the conclusion stems from: School is deeply immoral.

16 Ibid.

17 Respectively: M. Mazur, Szkoła bez lęku, „Argumenty”, 42 (1966) pp. 5, 10; M. Mazur, Integracja nauczania, „Argumenty”, 12 (1967) pp. 1, 6; M. Mazur, Informacja - dezinformacja-pseudoinformacja, „Argumenty”, 22 (1967) pp. 1, 6-7.

18 M. Mazur, Źle z historii. 
It is also immoral and contrary to Mazur's principle of homeostasis that the 'permanent overloading students to the limit of their endurance', often results in serious disorders and even tragic outcomes for students.

Interesting in this methodical point is his suggestion of using the method of programmed learning with the use of machines (and today, easily accessible computers), just in time for Mazur, developed by Czesław Kupisiewicz in his mixed programmed learning concept, containing appropriate configurations of such parts as: informational ones (a machine, unlike a teacher, is very patient with a student), repetitive, controlling, examinatory (then exams are really fair), alongside problematic ones. ${ }^{19}$

Moreover, it is worth mentioning here that in 1920 Stanisław Trębicki was the world pioneer of implementation works in this aspect of 'programmed' or 'machine learning'. Claiming to be a pioneer in this field, the American, Sidney L. Pressey, began his activities only a few years later. ${ }^{20}$

The use of machines would also eliminate the need for 45-minute 'sit-outs' of the prescribed lesson time, and the entire training cycle could be shortened by 'a year or two', according to Mazur. Thus, the additional effect would be economic benefits for society and for the students themselves.

Exams and tests, however, would concern only the planned and clearly defined 'information', with the exclusion of presenting 'politically correct' views by students, while the development of the views - let's emphasise this: not susceptible to examination and assessment - could be attained by school debates, also conducive to ethical education.

Contrary to concerns about the reduction of teachers' employment due to the use of programmed education, Mazur points to the fundamental teaching function: being an 'advocate', and thus a person supporting the student. The same was mentioned by L. Wygotski and J. Bruner. ${ }^{21}$

Oddly enough, the developments and implementations in the field of programmed learning have not been used at all, neither in Poland nor in other countries, to provide effective education for children and adolescents who have

19 C. Kupisiewicz, Nauczanie programowane, Warszawa 1966.

20 Data according to: W. Okoń, Wprowadzenie do dydaktyki ogólnej, Warszawa 1998.

21 E. Filipiak, Z Wygotskim i Brunerem w tle: Słownik pojęć kluczowych, Bydgoszcz 2011. 
the appropriate competences in using software during the current and longterm lockdown caused by the CoviD-19 pandemic.

Mazur also questions the legitimacy of dividing school content into teaching 'subjects', suggesting the so-called 'Cross-curricular teaching integration' (which he does as early as 1967, while the identical solution was implemented in the USA as an 'integrated curriculum' or 'unit study approach', only since the 1990s), and whose integration would result from the cybernetic concept of feedback to optimise the state of a system. ${ }^{22}$

Although in order to solve real, multidimensional optimisation problems it is necessary to have basic knowledge and skills in subject areas from the very beginning, it does not mean, however, that at the level of compulsory school education it would not be possible to implement a more modest version of 'integration' training, that is, thinking concepts and action strategies. This is what 'meta-learning' (learning to learn) would be. ${ }^{23}$ At school, unfortunately, we still have to deal with bureaucratic boxes, the administrators of which are blind to the full ethical and educational responsibility towards the young generation.

A unique part of this educational responsibility is to enable students, as part of helping them form their views, to criticise proposed claims, make claims, disagree with others, and express dissatisfaction. Students need to be allowed to make training decisions. In this way, they also learn mature responsibility, instead of rigid reliability in the implementation of solutions to tasks imposed by someone else, which is characteristic of slaves.

The so-called 'student councils' do not serve this aim. This only gives the appearance of representative democracy, with its many shortcomings. In this respect, Mazur goes as far as to suggest that compulsory education for teenagers is harmful. Teenagers, according to him, should start managing their own education themselves at their age. This would lead to the rational homeostatic regulation of individual biographies and the functioning of entire socie-

22 M. Mazur, Integracja nauczania.

23 M. Kolber, Uczymy się, jak się uczyć- kilka uwag o umiejętności uczenia się „ „Forum Dydaktyczne", 5-6 (2009) pp. 138-144. 
ties. A truly radical vision. But is it wrong? 'The state of education is simply desperate,' says Mazur, rightly. ${ }^{24}$

\section{Conclusions}

The educational recipes of Marian Mazur with a truly healing value, built on cybernetic, consistent diagnoses and common educational sense (who among us does not think like him?), are worth not only academic attention and further discussions, but maybe also the start of pilot experiments, real implementations in educational practice.

In place of the immobile, tarnished educational political decision-makers and their ministerial officials, alternative educational activists may implement Mazur's ideas, acting in this regard in a very 'cybernetic spirit'! It is possible to reconcile cybernetics and humanistic spirituality with its illuminations for the good of people.

Pompey the Great was right; when feeling responsible for the fate of his countrymen from the capital city of Rome, in order to save them from hunger due to the lack of food supplies, he ordered his sailors to set off from the shores of Africa into the stormy waters of the Mediterranean Sea. To paraphrase his words, let's say: 'Public education is not necessary; it is necessary to rationally navigate the education we already have.' The art of navigating education should be entrusted to truly competent pedagogical 'helmsmen' - scholars and experienced, but also creative, educational practitioners.

Streszczenie: Artykuł prezentuje cybernetyczne ujęcie i takież uzasadnienia dla wyróżniania wad w funkcjonowaniu dzisiejszej, jednak ciagle niezmiennej, masowej szkoły autorstwa Mariana Mazura, twórcy polskiej szkoły cybernetyki. Autor ten analizuje wszystkie istotne wymiary funkcjonowania szkół - od treściowych, przez metodyczne do organizacyjnych - wskazując na racjonalność optymalizacyjnego podejścia cybernetycznego do edukacji, który kongenialnie zgodny jest ze zdroworosądkowym odczuciem wobec słabości szkół. Choć analizy M. Mazura datują się na lata 6o-te XX wieku, wydają się mieć zastosowanie także nie do tylko naszego kraju, ale i do całego dzisiejszego świata.

Słowa kluczowe: Marian Mazur, cybernetyka, edukacja, szkoła, sterowanie.

24 M. Mazur, Jaka szkoła?, „Przegląd Tygodniowy”, 22 (1984). 


\section{Bibliography}

Filipiak E., Z Wygotskim i Brunerem w tle: Słownik pojęć kluczowych, Bydgoszcz 2011.

Górny M. H., Naukowcy wyklęci. Część I - Ojciec polskiej cybernetyki, „Pro Fide Rege et Lege", 79 (2018) pp. 62-91.

Kolber M., Uczymy się, jak się uczyć - kilka uwag o umiejętności uczenia się, „Forum Dydaktyczne", 5-6 (2009) pp. 138-144.

Kopczyński O., Grammatyka dla szkół narodowych na klassę I, Warszawa 1788.

Kupisiewicz C., Nauczanie programowane, Warszawa 1966.

Kwieciński Z., Socjopatologia edukacji, Olecko 1995.

Lechowski J., Życiorys naukowy profesora Mariana Mazura (1909-1983), „Postępy Cybernetyki", 10 (1987) z. 2, pp. 7-20.

Mazur M., Cybernetyka i charakter, Warszawa 1976.

Mazur M., Cybernetyka, in: Szkoła a postęp techniczny, ed. T. Nowacki, Warszawa 1962, pp. 185-230.

Mazur M., Homeostaza społeczna, in: Procesy samoregulacji w oświacie. Problemy homeostazy społecznej, eds M. Pęcherski, J. Tudrej, Warszawa 1983, pp. 107-115.

Mazur M., Informacja - dezinformacja-pseudoinformacja, „Argumenty”, 22 (1967) pp. 1, 6-7.

Mazur M., Integracja nauczania, „Argumenty”, 12 (1967) pp. 1, 6.

Mazur M., Jaka szkoła?, „Przegląd Tygodniowy”, 22 (1984) p. 14.

Mazur M., Szkoła bez lęku, „Argumenty”, 42 (1966) pp. 5, 10.

Mazur M., Tajemnice charakteru czyli poznaj samego siebie, Warszawa 1999.

Mazur M., Twór skostniały, „Argumenty”, 27 (1965) pp. 1, 6.

Mazur M., Źle z historii, „Argumenty”, 11 (1966) pp. 4, 6.

Mazur M., Źle z języków obcych, „Argumenty”, 40 (1965) pp. 2-3.

Mazur M., Źle z matematyki, „Argumenty”, 27 (1966) pp. 1, 6.

Mazur M., Źle z polskiego, „Argumenty”, 35 (1965) pp. 5, 8.

Okoń W., Wprowadzenie do dydaktyki ogólnej, Warszawa 1998.

Wilsz J., Poglądy profesora Mariana Mazura na temat edukacji w kontekście teorii systemów autonomicznych, „Kształcenie Zawodowe: Pedagogika i Psychologia”, 15 (2013) pp. 125-149. 